\title{
Hissiatri muistelee
}

\author{
Ilkka Mäntyvaara'
}

Sakari Aalto: Hissikuilun partaalta - tarkastajan muistelmat, toim. Kai Tarkka, Kiwa Inspecta 2020, 131 s, ISBN 978-952-94-3079-6

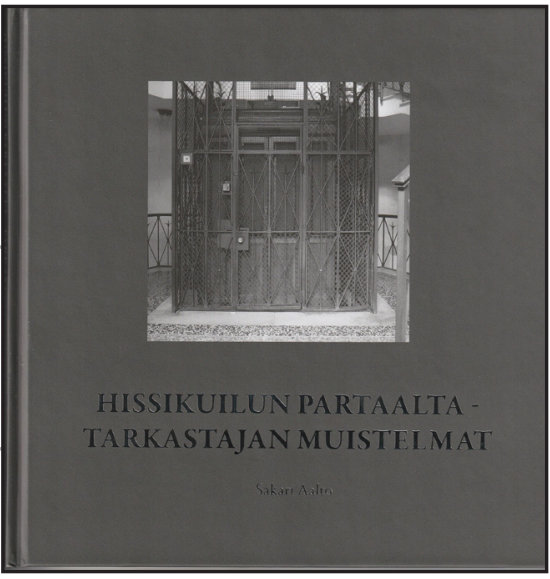

Sakari Aalto on tehnyt yli 40 vuoden uran hissitarkastajana ja muissa hisseihin liittyvissä tehtävissä. Jäädessään eläkkeelle Inspecta Tarkastus osakeyhtiöstä hän sai työtovereiltaan ainutlaatuisen arvonimen hissiatri. Töiden ajalta hänelle on kertynyt paljon omakohtaisia muistoja ja kirjallista aineistoa, joihin tämä kirja perustuu. Hissialalta on julkaistu vähän suomenkielistä kirjallisuutta ja varsinkin hissien tarkastus lienee useimmille varsin tuntematonta toimintaa. Tästä syystä on tervehdittävä ilolla näitä muistelmia, joista saa paljon hisseihin ja niiden tarkastukseen liittyvää tietoa. Kirja on hissialalle sopivasti jaettu lukujen sijasta kerroksiin. Ensimmäisessä kerroksessa on mielenkiintoinen kuvaus erilaisista hissityypeistä sekä hissin historiasta Suomessa ja maailmalla.

Toinen kerros käsittelee hissien turvallisuutta, turvalaitteita ja turvallisuuden kannalta kriittisiä kohtia. Tarkastuksia tarvitaan turvalaitteiden toiminnan sekä hissin käytön turvallisuuden varmistamiseksi. Hisseillä sattuneiden tapaturmien syyt on selvitettävä, jotta niistä voidaan ottaa oppia hissimääräysten kehittämiseen. Jonkin turvalaitteen toimiminen aiheuttaa yleensä hissin välittömän pysähtymisen. Kirjassa on esimerkkejä tilanteista, joissa on jouduttu pelastamaan ihmisiä kerrosten välille pysähtyneistä hisseistä. Pelastamiseen liittyy monia riskejä, minkä takia sen saa tehdä vain tehtävään koulutettu henkilö.

Kolmannessa kerroksessa kuvataan hissitarkastuksen yli 100-vuotista historiaa Suomessa sekä tänä aikana tapahtunutta hissien turvallisuusmääräysten kehitystä. Tämä on ainoa näkemäni julkaisu, jossa hissimääräysten alkuvaiheita on käsitelty näin perusteellisesti. Aloitteen hissimääräysten laatimisesta teki Tekniska föreningen i Finland. Yhdistyksen työryhmä sai vuonna 1901 aikaan ehdotuksen hissitoiminnan ohjesäännöksi. Sen perusteella Helsingin kaupunki julkaisi maan ensimmäiset hissimääräykset vuonna 1906 ja perusti hissitarkastajan viran. Valtakunnallisiksi hissimääräykset ja -tarkastus, muuttuivat vasta 1930-luvulla, kun oli perustettu Sähkötarkastuslaitos (myöhemmin Sähkötarkastuskeskus). Suomen liityttyä Euroopan Unioniin vuonna 1995 hissimääräysten kehittäminen on jäänyt pitkälti EU:n vastuulle. Suomessa erotettiin tuolloin toisistaan viranomaistoiminta ja tarkastustoiminta. Sähkötarkastuskeskuksen tarkastajista pääosa siirtyi Sähkötarkastus Fimtekno Osakeyhtiöön ja syntyi myös muita tarkastusyrityksiä, joista kirjassa on lyhyet kuvaukset.

\footnotetext{
${ }^{1}$ Ilkka Mäntyvaara on diplomi-insinööri, joka on toiminut yli 40 vuoden ajan hissialan tehtävissä Valmet Oy:ssä ja Otis Oy:ssä. Tuona aikana hän on osallistunut myös hissejä koskevien standardien ja turvallisuusmääräysten kehitystyöhön Suomessa ja ulkomailla.
} 
Neljännessä kerroksessa tulee esille hissitarkastajien koulutus ja Sakari Aallon toiminta kouluttajana ja hissiurakoitsijoiden töidenjohtajien pätevyyden arvioijana. Siinä kuvataan myös hänen osallistumistaan hissiturvallisuuden kehittämiseen monissa eri työryhmissä sekä kauppa- ja teollisuusministeriön sähköturvallisuuden neuvottelukunnassa. Lisäksi on kuvattu hissitarkastajan tärkeimpiä yhteistyökumppaneita, joita ovat vuodesta 1995 alkaen hissiviranomaisena toimineen Tukesin lisäksi hissiurakoitsijat ja heidän kattojärjestönsä Suomen Hissiyhdistys ry.

Viides kerros kuvaa hissitarkastajan arkipäivää ja tarkastustoiminnan alueellista organisointia. Viikossa oli yleensä yksi toimistopäivä paperitöitä varten ja muina päivinä kierrettiin hisseillä. Tarkastuksissa oli yleensä mukana hissin valmistajan tai huoltajan edustaja. Tarkastustyötä kuvataan melko yleisellä tasolla.

Kuudennessa kerroksessa tutustutaan lähemmin erilaisiin tarkastuksiin. Tarkastuksia tehdään uusille hisseille ennen niiden käyttöönottoa ja käytössä oleville hisseille säädöksissä määrätyin välein. EU:n hissidirektiivi on tuonut mukanaan myös hissien tyyppitarkastukset, joita ilmoitettu tarkastuslaitos (notified body) voi suorittaa. Tyyppitarkastuksia tehdään myös yksittäisille turvalaitteille, joiden on täytettävä hissidirektiivin vaatimukset. Tekstissä on tässä kohden pieni epätarkkuus, sillä siinä mainittuja ETY-tyyppitarkastuksen aikaisia kansallisia poikkeuksia ei hissidirektiivi enää salli.

Uuden tarkastajan perehdytys alkaa yleensä määräaikaistarkastuksista vanhemman tarkastajan opastuksella. Sakari Aalto kuvaa myös omaa perehdytystään ja ensimmäisiä tarkastuksia uransa alussa sekä määräaikaistarkastuksissa löytyviä tyypillisiä vikoja. Lukijan kannalta olisi ollut selkeämpää, jos erilaiset tarkastukset olisi esitelty ennen tarkastajan arkipäivää eli kirjan kuudes ja viides kerros olisivat vaihtaneet paikkaa.

Seitsemäs kerros esittelee eräitä kiinnostavia tarkastuskohteita vuosien varrelta. Niitä ovat olleet mm. Loviisan ydinvoimala ja hissi Pyhäsalmen kaivoksessa 540 m syvyydellä sekä Svetogorsk ja Kostamus Neuvostoliitossa.

Kahdeksas kerros vie lukijan nykyaikaan. Siinä kirjan toimittaja Kai Tarkka on haastatellut kahta vielä työssä olevaa hissitarkastajaa. Uudet hissit ovat entistä monimutkaisempia, mutta hissiturvallisuuden perusta on edelleen sama: yksikin vika missä tahansa turvallisuuden kannalta tärkeässä hissin osassa pysäyttää hissin ja estää sen käytön. Hissitarkastajista on entistä selvemmin tullut asiakaspalvelijoita, joiden tehtävänä on auttaa hissin haltijaa pitämään hissinsä turvallisina.

Kirjan toimitustyön on tehnyt Kai Tarkka ja taiton sekä ulkoasun on suunnitellut Jaana Pusa. Lukujen eli kerrosten väliin on sijoiteltu hauskasti välilehtiä, joissa on kerrottu joku aiheeseen liittyvä pieni tarina. Kirjaan valitut valokuvat ja kaaviot täydentävät tekstiä sopivasti. Kirjan liitteenä on sanakirja hissitarkastus-suomi, jossa on selitetty eräitä hissitarkastajien ja -asentajien käyttämiä sanoja, jotka poikkeavat virallisesta terminologiasta. Toisena liitteenä on tilastotietoa hisseistä ja hissitarkastuksista.

Kirjassa on kattava lähdeluettelo, mutta ei lähdeviitteitä. Kun siinä on mainittu minunkin kirjoitelmiani, haluaisin todeta, että Hissien standardisointibistoria ja Muistelmia hissistandardoinnista ja hissimääräysten kehityksestä Suomessa ja maailmalla ovat itse asiassa sama teksti. Se on ollut metsta.fi-sivustolla vuodesta 2008 lähtien, mutta olen täydentänyt sitä vuonna 2017.

Kirjaa voi hyvin lukea ilman ennakkotietoja hisseistä. Siinä on paljon mielenkiintoista tietoa kaikille, jotka ovat kiinnostuneita hisseistä ja niiden turvallisuudesta, mutta myös hissialan ammattilaisille tai alalle aikoville. 